\title{
ADIPONECTIN AND TUMOR NECROSIS FACTOR ALPHA LEVELS, AND THEIR CORRELATIONS WITH ENDOTHELIAL DYSFUNCTION IN CENTRAL OBESITY
}

\author{
${ }^{1}$ Frans Wantania \\ ${ }^{1}$ Reginald L. Lefrandt \\ ${ }^{2}$ Karel Pandelaki
}

\author{
${ }^{1}$ Cardiology Department Medical Faculty Sam Ratulangi University Manado \\ ${ }^{2}$ Internal Medicine Department Medical Faculty Sam Ratulangi University Manado \\ Email: Akuaku_ukauka@ymail.com
}

\begin{abstract}
Abstrak: Pada obesitas, makrofag yang berinfiltrasi ke jaringan adiposa akan mengakibatkan kondisi inflamasi. Selain itu, jaringan adiposa melepaskan sitokin proinflamasi seperti TNF alfa. Sitokin-sitokin ini memicu oksidasi LDL oleh ROS, dan mempercepat degradasi NO, yang berakibat disfungsi endotel. Adiponektin yang dapat mencegah disfungsi endotel ternyata menurun oleh kerja TNF alfa. Tujuan penelitian ini untuk menentukan kadar TNF alfa dan adiponektin serum, serta hubungannya dengan disfungsi endotel. Penelitian ini merupakan studi observasi, deskriptif, dan analitik dengan cross sectional. Sebagai sampel digunakan siswa SMU di Manado. Metode sampling diambil secara berurut sampai jumlah yang ditargetkan tercapai. Data terdiri dari usia, tekanan darah, lingkar pinggang, berat badan, profil lemak, kreatinin, TNF alfa, adiponektin, dan rasio albumin kreatinin. Untuk menganalisis data digunakan Spearman correlation. Setelah selang waktu empat bulan, ditemukan 35 siswa laki-laki obes dengan kisaran usia 16-18 tahun. Rerata berat badan 83,23 $\mathrm{kg}$ dan rerata lingkar pinggang 103,94 cm. Disfungsi endotel ditemukan pada 5,72\% sampel, kadar TNF alfa tinggi pada 68,57\%, dan adiponektin rendah 62,8\%. Diperoleh korelasi positif bermakna antara TNF alfa dan disfungsi endotel $(r=0,554, \mathrm{p}<0,000)$, dan korelasi terbalik antara kadar adiponektin dan disfungsi endotel $(r=-0,349, \mathrm{p}=0,020)$.
\end{abstract}

Kata kunci: obesitas, adiponektin, TNF alfa, disfungsi endotel

\begin{abstract}
In obesity, macrophages that infiltrate into adipose tissues create an inflammatory condition. Besides that, adipose tissues release pro-inflammatory cytokines such as TNF alpha. These cytokines promote LDL oxydation by ROS, and accelerate NO degradation resulting in endothelial dysfunction. Adiponectin which could prevent endothelial dysfunction is decreased secondarily to TNF alpha's action. The objectives of this research were to determine the serum levels of TNF alpha and adiponectin, and their correlations with endothelial dysfunction. This was an observational, descriptive, and analytic study with cross sectional study. Samples were students of senior high schools in Manado. The sampling method was carried out consecutively until the required number was enough. Data consisted of age, blood pressure, waist circumference, body weight, lipid profile, creatinin, TNF alpha, adiponectin, and an albumin-to-creatinine ratio. We used the Spearman Correlation to analyze the data. Over a 4-month period, there were 35 obese male subjects with ages of 16-18 years old. The average of body weights was $83.23 \mathrm{~kg}$, and of waist circumferences was $103.94 \mathrm{~cm}$. Among the samples, endothelial dysfunction was found in $5.72 \%$, high levels of TNF alpha in $68.57 \%$, and low levels of adiponectin in $62.8 \%$. We found a significant positive correlation between TNF alpha, and endothelial dysfunction $(\mathrm{r}=0.554, \mathrm{p}<0.000)$, and an inverse correlation between adiponectin levels, and endothelial dysfunctions $(r=-0.349, p=0.020)$.
\end{abstract}

Keywords: obesity, adiponectin, TNF alpha, endothelial dysfunction 
Obesity is a condition characterized by excess fat accumulation in adipose tissue. This state and the associated metabolic pathologies are the most common and detrimental metabolic diseases, affecting over $50 \%$ of the adult population. These conditions are associated with chronic inflammatory responses characterized by abnormal cytokine production, increased acute-phase reactants, and activation of inflammatory signaling pathways. ${ }^{1}$

In obese people, adipose tissues are characterized by inflammation and progressive infiltration by macrophages as obesity developes. ${ }^{2}$ Changes in adipocyte and fat pad sizes lead to physical changes in the surrounding areas and modifications of the paracrine function of the adipocytes. ${ }^{3}$ Next, adipose tissues release the proinflammatory cytokines such as tumor necrosis factor (TNF) alpha. These cytokines promote LDL (low density lipoprotein) oxidized by ROS (reactive oxygen species), and accelerate NO degradation resulting in endothelial dysfunction. ${ }^{4}$

Several in-vitro studies have demonstrated that adiponectin has anti-inflammatory and anti-atherosclerotic actions that include reducing expression of adhesion molecules on endothelial cells and increasing NO production. ${ }^{5}$ The circulating levels of adiponectin are approximately one thousand-fold higher than other adipocytokines and hormones. This disparity implies that over and above its central role in glucose and lipid homeostasis, adiponectin may also protect the vascular endothelium from injury. ${ }^{6}$ In obesity, adiponectin is decreased secondarily to TNF alpha's action. $^{4,6}$

Nowadays, obesity is a serious health problem in industrialized countries. Its prevalences have been steadily increasing during recent years and this trend is particularly pronounced in children and adolescents. ${ }^{7,8}$ It is essential to reduce body weight to prevent or treat these complications. However, diet and physical exercise are usually not very effective, and even after successful weight loss, most patients regain their weight. ${ }^{9}$ Moreover, the inflam- mation still going on, induces the endothelial dysfunction secondarily to TNF alpha. Recent study shows that childhood obesity is associated with the inflammatory process. $^{10}$

\section{OBJECTIVES}

The objective of this study is to determine the serum levels of TNF alpha and adiponectin, and their correlations with the endothelial dysfunction.

\section{SAMPLES AND METHODS.}

This cross-sectional study included 35 obese male subjects with an age range of 16-18 years old. They were students of senior high schools in Manado that had waist circumferences of $\geq 90 \mathrm{~cm}$. Sampling was carried out until the required number was sufficient, and from this, the sampling data consisted of age, blood pressure, waist circumference, body weight, lipid profile, creatinine, TNF alpha, adiponectin, and an albumin-to-creatinine ratio (ACR). Patients with evidence of acute inflammatory diseases were excluded. The study was conducted after obtaining informed consent from all the subjects.

Brachial blood pressure was measured with a mercury sphygmomanometer after 30 minutes of rest in the supine position. Venous blood was drawn after an overnight fast. Total cholesterol, triglycerides, HDL cholesterol, and glucose concentration were determined by using enzymatic methods. Plasma adiponectin concentration was determined by using the ELISA kit (Otsuka Pharmaceutical Co, Ltd). The concentrations of TNF alpha in blood serum were measured by using a commercially available highly sensitive ELISA kit. Assessment of endothelial dysfunction was determined by using the albumin-to-creatinine ratio test to assess the microalbuminuria (30-300 ug/mg creatinine). There is a consensus that diagnosing microalbuminuria requires two of three consecutive samples within the range. ${ }^{11}$

The data were shown as the mean 
+ SD. All statistical analyses were performed using the Statistical Package for Social Science (SPSS). Spearman correlation analysis was used to test the correlations between adiponectin, TNF alpha levels and the ACR.

\section{RESULTS}

Distribution of ages, mean of waist circumference, and endothelial dysfunction

Over 4 month period, there were 35 obese male subjects with an age range of 16-18 years old. The average body weight was $83.23 \mathrm{~kg}$ with waist circumferences averaging $103.94 \mathrm{~cm}$. Endothelial dysfunction was found in $5.72 \%$ of samples and "high normal" ACR in $11.4 \%$ of samples (Fig.1)

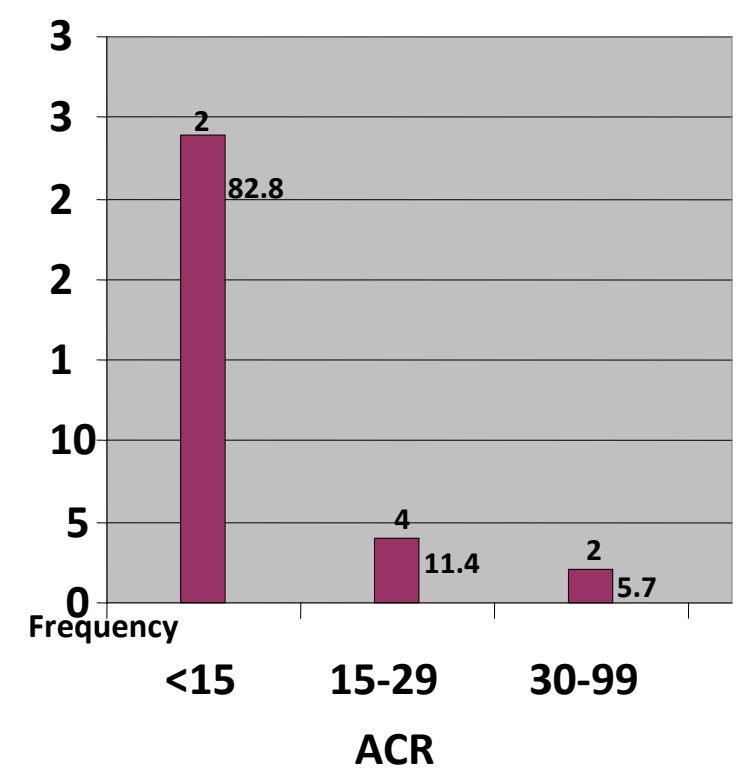

Figure 1. Distribution of albumin to creatinine ratio (ACR).

\section{TNF alpha and adiponectin levels}

Figure 2 shows TNF alpha levels in obese adolescence. We found $68.57 \%$ of the samples had high levels of TNF alpha, and $62.86 \%$ with low levels of adiponectin (Fig. 3).

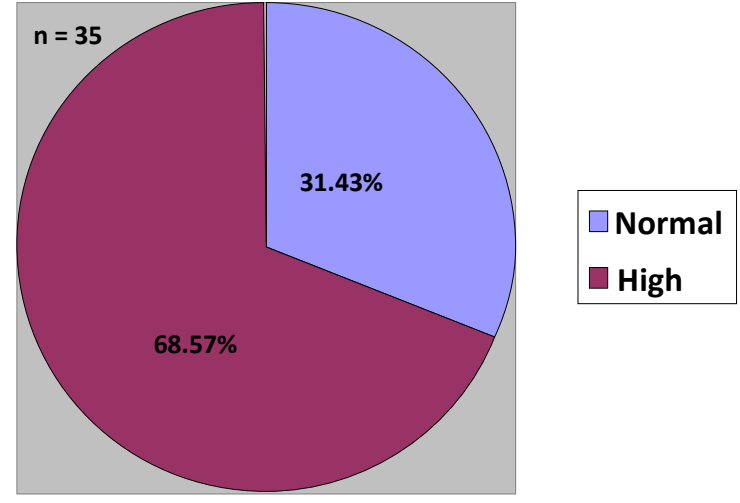

Figure 2. TNF alpha levels in obese adolescence.

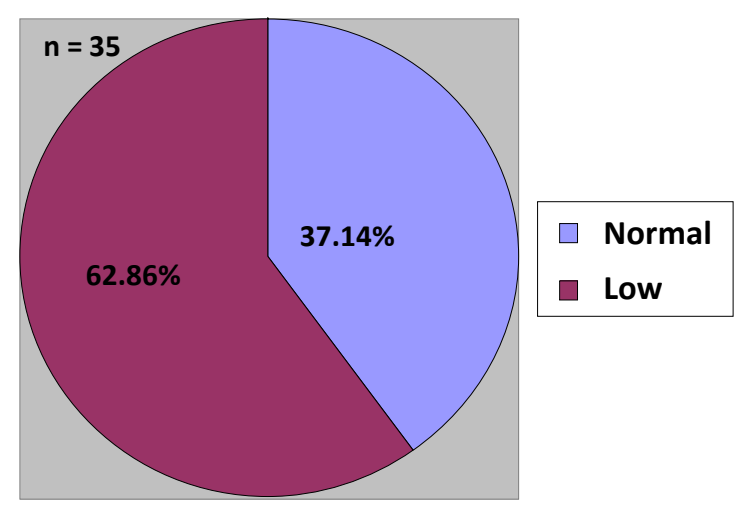

Figure 3. Adiponectin levels in obese adolescent people.

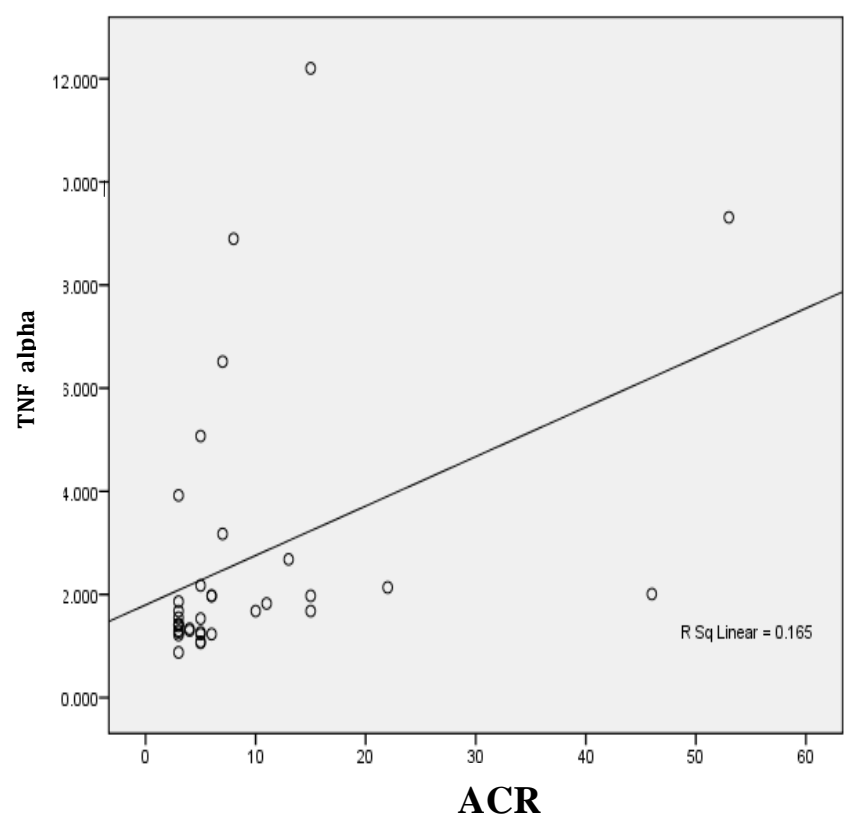

Figure 4. Correlation between TNF alpha levels and ACR. 


\section{Correlation between TNF alpha levels and endothelial dysfunction}

We found a significant positive correlation between TNF alpha levels and endothelial dysfunction $(\mathrm{r}=0.554, \mathrm{p}<0.000)$ (Fig.4). This study found that the plasma adiponectin levels were inversely correlated with endothelial dysfunction $(\mathrm{r}=$ $0.349, \mathrm{p}=0.020$ ) (Fig.5).

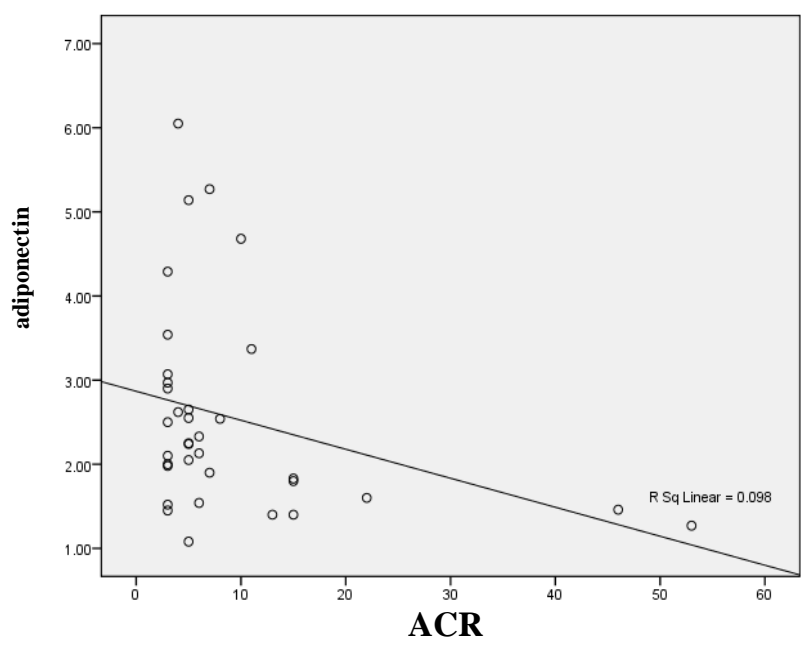

Figure 5. Correlation between adiponectin levels and ACR

\section{DISCUSSION}

Previous study reported that serum adiponectin was decreased and TNF-alpha levels were increased in obese Korean children. Their findings suggested that childhood obesity is associated with inflammatory processes. $^{10}$ Our findings suggest that the same processes happen in obese adolescence. In obesity, adipocytes begin to secrete low levels of TNF-alpha, which can stimulate preadipocytes to produce monocyte chemoattractant protein1 (MCP-1). In response to cytokine, endothelial cells also secrete MCP-1. Thus, either preadipocytes or endothelial cells could be responsible for attracting macrophages to adipose tissue. ${ }^{12}$ Whatever, the initial stimulus to recruit macrophages into adipose tissue is, once these cells are present and active, they, along with adipocytes and other cell types, could perpetuate a vicious cycle of macrophage recruitment, production of inflammatory cytokines, and impairment of adipocyte function. ${ }^{1}$

Elevated levels of interleukin-6, TNFalpha, and presence of insulin resistance lead to a decrease in production and availability of endothelial nitric oxide synthase resulting in endothelial dysfunction. ${ }^{13}$ In this study we found microalbuminuria as a parameter of endothelial dysfunction in $5.72 \%$ of samples and "high normal" ACR in $11.4 \%$. A slightly elevated of ACR (15$30 \mathrm{ug} / \mathrm{ml}$ ) was associated with the increasing risk of cardiovascular events. The Copenhagen City Heart Study showed a 2.3 fold higher relative risk of cardiovascular events in the population with a "high normal" ACR (15-30 ug/ml) than normal ACR $(<15 \mathrm{ug} / \mathrm{ml}) .{ }^{11}$ Picchi et $\mathrm{al}^{14}$ found a decreased ability of endothelium vasodilatation in Zucker Obese Fatty (ZOF) rats. Endothelium-dependent vasodilation and $\mathrm{NO}$ production were attenuated in small coronary arteries from $\mathrm{ZOF}$ versus controled lean rats. Basal tone tended to be lower in the vessels isolated from $\mathrm{ZOF}$ rats versus those from lean rats.

The mechanisms linking microalbuminuria and risk for cardiovascular disease are not fully understood, but in subjects at risk it may be related to an increased transvascular leakiness of albumin in systemic as well as renal vessels. A recent concept is that microalbuminuria is a marker of extensive endothelial dysfunction or generalized vasculopathy, which may lead to heightened atherogenic states. One possible explanation is that endothelial dysfunction might promote increased penetration of atherogenic lipoprotein particles into the arterial walls. ${ }^{15}$ Previous studies reported the increased expression of the TNF-alpha mRNA in the adipose tissues of obese rodents and in obese human subjects. ${ }^{16,17}$ Zahorska observed increased serum levels of TNF-alpha in obese women in comparison with lean women. Body weight reduction in obese subjects was associated with a decrease in TNF-alpha mRNA expression in fat tissues and serum. ${ }^{18}$

In the present study, $68.57 \%$ of sam- 
ples had a high level of TNF alpha, and we found a significant positive correlation between TNF alpha and endothelial dysfunction $(r=0.554, p<0.000)$. The vascular endothelium is a major target for the actions of TNF-alpha. TNF-alpha can decrease the release of endothelial NO and induce impairment of endothelium-dependent vasodilation in a variety of vascular beds. ${ }^{19}$ Recent evidence supports the idea that the effect of TNF-alpha is NO dependent by producing a rapid inhibitory action on NO synthase (NOS) in the endothelium via activation of a sphingomyelinase/ceramide signaling pathway. This mechanism is supposed to mediate the action of TNF-alpha, thereby contributing to vascular endothelial dysfunction in coronary circulation under different pathological conditions with increased cytokines. ${ }^{20}$

In recent study, administration of antiTNF-alpha protected endothelial dysfunction induced by TNF-alpha in the isolated vessels of lean control rats. Impaired endothelium-dependent vasodilation was restored in ZOF rats after the treatment with TNF-alpha antibodies for three days, and this three-day treatment with TNF-alpha mimicked endothelial dysfunction with lean rats. TNF-alpha is known to affect eNOS expression by affecting the half-life of its mRNA. Picchi observed that $\mathrm{ZOF}$ rats generated little or no NO. The protein expression of eNOS was significantly attenuated in isolated arteries in $\mathrm{ZOF}$ rats compared with the lean animals. ${ }^{14}$

We found low levels of adiponectin in $62.86 \%$ of samples, and an inverse correlation between adiponectin and endothelial dysfunction $(\mathrm{r}=-0.349, \mathrm{p}=0.020)$. Plasma levels of adiponectin in humans are substantially high but levels are negatively correlated with body mass index. ${ }^{21}$ Shin observed that serum adiponectin level was decreased in Korean obese children. ${ }^{10}$ Matsuzawa reported that TNF-alpha was a strong inhibitor of adiponectin promoter activity. The negative correlation between visceral adiposity and adiponectin levels might be explained by the increased secretion from the accumulated visceral fat. ${ }^{21}$ Furukawa showed that in nondiabetic human subjects, fat accumulation closely correlated with the markers of systemic oxidative stress. They demonstrated that plasma adiponectin levels were correlated inversely with systemic oxidative stress. ${ }^{22}$

Experimental studies have indicated that adiponectin has potential anti-atherogenic and anti-inflammatory properties. When the vascular endotheliums are injured, adiponectin accumulates in the subintimal space of the arterial walls through its interaction with collagens in the vascular intima. Moreover, adiponectin also supperses lipid accumulation in monocyte-derived macrophages through the suppression of macrophage scavenger receptor expression. ${ }^{23}$

A recent report demonstrated that adiponectin had the direct action of stimulating the production of $\mathrm{NO}$ in endothelial cells. This direct stimulation depends on the pathway of Phosoatidylinositol-3-kinase involving phosphorylation of endothelial NO synthase (eNOS). ${ }^{23}$

Plant found that adiponectin attenuated the production of ROS and increased cell antioxidant defence system which was consistent with other published studies. ${ }^{24}$ Motoshima et al demonstrated adiponectin reduced the generation of ROS in endothelial cells exposed to oxLDL by attenuating the activity of plasmamembrane bound NADPH oxidase. $^{25}$ There was also some evidence that adiponectin increased antioxidant defence systems. Jung et al reported that human adiponectin protected neuroblastoma cells from neurotoxin induced ROS production by increasing the expression of catalase and superoxide dismutase. ${ }^{26}$

Vascular endothelial dysfunction plays a pivotal role in the pathogenesis of atherosclerosis and enhances the risk of future cardiovascular events. Because adiponectin may protect the endothelium from early atherosclerotic events such as the expression of adhesion molecules or the attachment of monocytic cells, hypoadiponectinemia could be related to endothelial damage. ${ }^{23}$ 


\section{CONCLUSION}

There are high levels of TNF alpha and low levels of adiponectin in a moderate number of samples. There was a significant correlation between serum TNF-alpha levels and endothelial dysfunction. There was an inverse correlation between serum adiponectin levels and endothelial dysfunction. Further study is needed to determine the serum levels of TNF-alpha and adiponectin in non obese adolescence. It is important to treat the obese adolescence early to prevent the cardiovascular events.

\section{REFERENCES}

1. Wellen KE and Hotamisligil GS. Obesityinduced inflammatory changes in adipose tissue. J Clin Invest. 2003; 112:1785-8.

2. Weisberg SP, McCann D, Desai M, Rosenbaum M, Leibel RL, Ferrante AW, et al. Obesity is associated with macrophage accumulation in adipose tissue. J Clin Invest. 2003; 112:17961808.

3. Xu H, Barnes GT, Yang Q, Tan G, Yang D, Chou CJ, et al. Chronic inflammation in fat plays a crucial role in the development of obesity-related insulin resistance. J. Clin. Invest. 2003;112:1821-30.

4. Hajer GR, Haeften TW, and Visseren FLJ. Adipose tissue dysfunction in obesity, diabetes, and vascular diseases. Eur Heart Journal. 2008;29:2959-71.

5. Xi W, Satoh H, Kase H, Suzuki K, Hattori Y. Stimulated HSP90 binding to eNOS and activation of the P13-Akt pathway contribute in response to globular adiponectin. Biochem Biophys Res Commun. 2005;332:200-05.

6. Berg AH, Combs TP, Scherer PE. ACRP30/ adiponectin: an adipokine regulating glucose and lipid metabolism. J Endo Metab 2002;13:84-9.

7. Mokdad AH, Bowman BA, Ford ES, Vinicor F, Marks JS, Koplan JP. The continuing epidemics of obesity and diabetes in the United States. JAMA 2001; 286:1195-2000.

8. Styne DM. Childhood and adolescent obesity. Prevalence and significance. Pediatr Clin N Am 2001;48:823-54.
9. Glazer G. Long-term pharmacotherapy of obesity 2000. A review of efficacy and safety. Arch Intern Med. 2001;61:181424.

10. Shin JY, Kim SY, Jeung MJ, Eun DH, Woo CW, Yoon SY, et al. Serum adiponectin, C-reactive protein, and TNF-alpha levels in obese Korean children. Journal of Pediatric Endocrinology \& Metabolism. 2008;21:23-9.

11. Lumeng CN, Bocizin JL, Saltiel AR. Obesity induces a phenotypic switch in adipose tissue macrophage polarization. J. Clin. Invest. 2007;117:175-84.

12. Hopkins TA, Ouchi N, Shibata R, Waish K. Adiponectin actions in the cardiovascular system. Cardiovasc Res. 2007;74:11-8.

13. Rose RD, Bakris GL. Microalbuminuria and cardiovascular disease. In: Rose $\mathrm{BD}$, editor. Up To Date. Wellesley (MA): UpToDate, 2004.

14. Picchi A, Gao X, Belmadani S, Potter BJ, Focardi M, Chilian WM, et al. Tumor necrosis factor-alpha induces endothelial dysfunction in the prediabetic metabolic syndrome. Circ Res. 2006;99:69-77.

15. Naidoo DP. The link between microalbuminuria, endothelial dysfunction and cardiovascular disease in diabetes. Cardiovasc J S Afr. 2002;13(4):194-9.

16. Hotamisligil GS, Arner P, Caro JF, Atkinson RL, Spiegelman BM. Increased adipose tissue expression of tumor necrosis factor-alpha in human obesity and insulin resistance. $\mathrm{J}$ Clin Invest. 1995;95:2409-15.

17. Kern PA, Saghizadeh M, Ong JM, Bosch RJ, Deem R, Simsolo RB. The expression of tumor necrosis factor in human adipose tissue. Regulation by obesity, weight loss, and relationship to lipoprotein lipase. J Clin Invest. 1995;95:2111-9.

18. Zahorska B, Janowska J, Olszanecka M, and Zurakowski A. Serum concentrations of TNF-alpha and soluble TNFalpha receptors in obesity. International Journal of Obesity. 2000;24:1392-5.

19. Zhang C, Xu X, Wang W, Michael L, Kuo L, and Chilian WM. TNF-alpha contributes to endothelial dysfunction in ischemia/reperfusion injury. Arterioscler Thromb Vasc Biol. 2006;26:475-80. 
20. Zhang DX, Yi FX, Zou AP, Li PL. Role of ceramide in TNF-alpha induced impairment of endothelium-dependent vasorelaxation in coronary arteries. Am J Physiol Heart Circ Physiol. 2002;282:1785-94.

21. Matsuzawa Y, Funahashi T, Kihara S, Shimomura I. Adiponectin and metabolic syndrome. Arterioscler thromb Vasc Biol. 2004;24:29-33.

22. Furukawa S, Fujita T, Shimabukuro $M$, Iwaki M, Yamada Y, Nakajima $Y$ et al. Increased oxidative stress in obesity and its impact on metabolic syndrome. J Clin Invest. 2004;114:1752-61.

23. Ekmekci H and Ekmekci OB. The role of adiponectin in atherosclerosis and thrombosis. Clin Appl Thrombosis/
Hemostasis. 2006;12(2):163-8.

24. Plant S, Shand B, Elder P, and Scott $R$. Adiponectin attenuates endothelial dysfunction induced by oxidized lowdensity lipoproteins. Diabetes Vasc Dis Res. 2008;5:102-8.

25. Motoshima H, Wu X, Mahadev K, Goldstein BJ. Adiponectin suppresses proliferation and superoxide generation and enhances eNOS activity in endothelial cells treated with oxidized LDL. Biochem Biophys Res Commun. 2004;315:264-71.

26. Jung TW, Lee JY, Shim WS, et al. Adiponectin protects human neuroblastoma SH-SY5Y cells against MPP+ induced cytotoxicity. Biochem Biophys Res Commun. 2006;343:564-70. 